\title{
Influence of Leadership Style, Work Culture and Work Satisfaction on Employee Engagement in The Ministry of Defense of The Republic of Indonesia
}

\author{
Andarias Pong Bija* \\ Doctoral Candidate Management of Human Resource, Universitas Negeri Jakarta \\ Hamidah \\ Management of Human Resource, Universitas Negeri Jakarta \\ Billy Tunas \\ Management of Human Resource, Universitas Negeri Jakarta \\ Dedi Purwana \\ Management of Human Resource, Universitas Negeri Jakarta
}

The research is financed by Asian Development Bank. No. 2006-A171(Sponsoring information)

\section{Abstract}

This study aims to describe the Management of Human Resources, especially the Management of the State Civil Apparatus (ASN) in the Ministry of Defense of the Republic of Indonesia, through a description of the influence of leadership style, work culture, and work satisfaction on employee engagement. Lack of discipline and employee work ethic, which can be seen from the number of employees who are late and skipping work, are still less concerned with their performance, thus showing an indication of low employee engagement. This research used explanative research with a quantitative approach. Data collection was carried out by survey using a questionnaire with a proportional sampling technique. This research worked together with 37 people from the Directorate General of Defense Forces, and 38 of them taken from the Directorate General of Defense Strategy (57.4\%). The results of this study indicate (1) the leadership style has a direct positive effect on employee engagement. (2) Work culture has an immediate positive effect on Employee Engagement. (3) Work satisfaction has a direct positive effect on Employee Engagement. (4) Leadership style has a direct positive effect on work satisfaction. (5) Work culture has a direct positive effect on work satisfaction. (6) Leadership style has a direct positive effect on work culture. (7) Leadership style has a positive indirect effect on Employee Engagement through work culture. (8) Leadership style has an indirect effect on Employee Engagement through work satisfaction and (9) Work culture has a positive indirect effect on employee engagement through work satisfaction. Based on the results of the study concluded that leaders in the Ministry of Defense are advised to promote transformational leadership styles that are able to foster a positive work culture and increase work satisfaction of subordinates (State Civil Apparatus and Military). Also, implement them at various levels of leadership positions within the Ministry of Defense so that employee engagement can grow in all units and organizational levels of the Ministry of Defense.

Keywords: leadership style, work culture, work satisfaction, employee engagement, the ministry of defense

DOI: $10.7176 / \mathrm{JRDM} / 68-04$

Publication date:August $31^{\text {st }} 2020$

\section{Introduction}

Brain drain is a science-based economic transition that is able to create a more integrated market share for those who have high talent and expertise (Golovics, 2019). The phenomenon of brain drain occurs in many developing countries and developing countries (Dodani \& LaPorte, 2005). Indonesia, which is still a developing country category, also needs to be aware of the phenomenon of brain drain, especially with the increasingly easy opportunities for the transfer of experts in line with the enactment of the ASEAN Economic Community (AEC) agreement. Brain drain in Indonesia, although not yet supported by official data, is estimated to have reached 5\% (Pella \& Inayati, 2011). The number is indeed relatively small compared to Haiti, which experienced a brain drain rate reaching $80 \%$, which is the country with the highest brain drain rate in the world (Joseph, 2011). However, the $5 \%$ figure is very influential when the high demand for qualified human resources for national development and the still low performance of educational and training institutions in Indonesia. The brain drain phenomenon shows the important role of Human Resources (HR), both in the context of nation-states and organizations (Singh \& Krishna, 2015).

According to Rachmawati (2013), Markos and Sridevi have proposed a concept of employee engagement that is actually a development of management techniques from Organizational Behavior Citizenship (OCB). Titien (2017) developed an instrument model that can measure employee engagement scores that refer to the theoretical 
framework proposed by Schaufeli, known as the Utrecht Work Engagement Scale (UWES). Dajani (2015) explained that employee engagement had an impact on organizational performance and commitment to the banking sector in Egypt. Siddhanta and Roy (2010), provide an explanation of how some organizations have the desire to develop employee engagement programs but have difficulty in practicing them. Sanneh and Taj (2015), provide an overview of employee engagement in the public sector in West Africa with a sample of the Gambian Port Authority. This study argues that research on employee engagement has been widely carried out in the private sector in the West, but still little by taking field studies in Africa. Sibanda et al. (2014) provide an affirmation of the relationship between Employee Engagement and organizational performance in the public sector in Zimbabwe. From Trang (2013), provides a reference on leadership styles in the public sector and organizational culture in relation to performance. Koech and Namusonge (2012), provide an overview of the leadership styles in state enterprises in Kenya.

Indonesia is also faced with integrity issues that plague the State Civil Apparatus. In the context of this integrity, Transparency International Indonesia (TII) places Indonesia in the 107th position of 174 countries in the Corruption Perception Index, with a score of 34 or only up 2 points compared to 2013 (Wahyudi, 2014). This position is far below Singapore, which ranks 7th with a score of 84. Malaysia in the 50th position (score 52), Thailand, and the Philippines, which simultaneously occupies the 85th position (score 38). However, according to Tambunan, in the current context of globalization, the country that will gain a competitive advantage is a country that has competitiveness (Tambunan, 2012: 4).

For this reason, the role of human resource management is needed, and then it becomes essential considering the impact on the perceptions, attitudes, and behaviour of members of the organization. With effective human resource management, organizations will get members who have perceptions, attitudes, and behaviours that support organizational performance. In the development of their knowledge, effective human resource management can cause employees to feel an attitude of positive engagement known as employee engagement (Shuck, Nimon, \& Zigarmi, 2017)

The link between employee engagement and leadership can be explained by Robinson et al. (Xu \& Thomas, 2011), which emphasizes the importance of leaders and managers in an organization. Therefore, the factors underlying the formation of engagement are the quality of proper organizational management so that they are able to value their employees and provide opportunities to get involved in the organization. Organizationally, the Ministry of Defense is unique as a civilian government organization, which carries out the main tasks of the defense sector. Following the characteristics of the main tasks it carries, the Ministry of Defense is manned by HR with active military backgrounds, even in many strategic positions, both at echelon 3 (three) and 2 (two) levels, especially in echelon 1 (one). This condition positively affects the pattern of leadership, work culture, and work satisfaction at the Ministry of Defense.

This condition certainly affects the pattern of leadership, work culture, and work satisfaction at the Ministry of Defense. This is an added attraction of research because previous studies and studies tend to get the same status conditions between leaders and subordinates, which are both civil status. At the same time, this research will actually face different conditions between leaders and subordinates. The leader, who will be assessed his leadership style, has the possibility of military or civil background, while the subordinates who will judge are civilians. In this way, the research problem becomes even more interesting because civilian subordinates can be assumed to be engaged due to the personal image of the leader with a military background. The characteristics of military leaders, who are often described as disciplined, assertive, and loyal, are also assumed to be able to contribute to the formation of civilian subordinate work culture. As such, as an inseparable part of national development, the role of the Ministry of Defense in determining retention and employee engagement strategies is a fairly central thought in dealing with brain drain and global competition. Thus, this study aims to describe the Management of HR, especially the Management of the State Civil Apparatur at the Ministry of Defense of the Republic of Indonesia, through a description of the influence of leadership style, work culture, and work satisfaction on employee engagement.

\section{Material and Methods}

This explanative research used a quantitative approach. There is a population of State Civil Apparatur in the Directorate General of Defense and Directorate General of Defense Strategy. This study uses a proportional sampling technique. From the determined sample of 75 people, 37 of which were taken from the State Civil Apparatur at the Directorate General of Defense and 38 samples were taken from the State Civil Apparatur at the Directorate General of Defense strategy (57.4\%). Data analysis techniques include descriptive statistical analysis and inferential statistical analysis. In this study, besides analyzing direct relationships, also analyzing indirect relationships. According to Sobel (Obeidat, 2016), some sources refer to this test as the delta method. It requires the standard error of a or (which equals a / ta, where ta is the test of coefficient) and the standard error of $b$ or $s b$. The Sobel test provides an approximates the estimate of the standard error of ab, which is equal to the square root of b2sa2 $+\mathrm{a} 2 \mathrm{sb} 2$.). Kristhoper J. Preacher and Geoffrey J. Leonardelli (Heckman, 2005) have an excellent webpage 
that can help these tests through the Sobel test. Measures and tests of indirect effects are also available in many structural equation modeling programs. These programs appear to use the Sobel formula. According to Kristopher J. Preacher and Geoffrey J. Leonardelli (Preacher \& Hayes, 2008), the reported value is taken from the normal distribution of units with the assumption of a two-sided z-test of the hypothesis which contains $95 \%$ of the unit's regular distribution center. It can be seen the equation that uses mediation, as outlined in Figure 1 below.

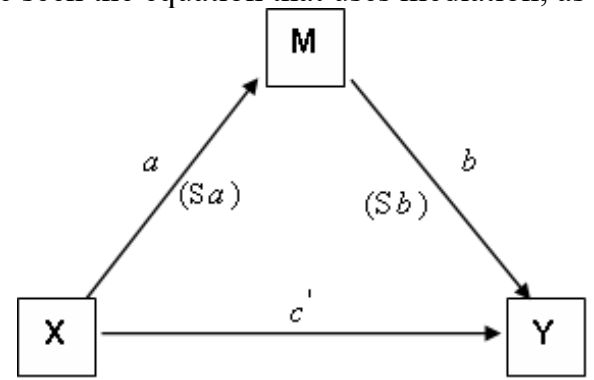

Figure 1. Regression with Mediation

source: MacKinnon, Warsi, \& Dwyer (1995)

\section{Results}

The data collected is data from four variables studied, namely Leadership Style, Work Culture, Work Satisfaction, and Employee Engagement. Based on the analysis of the research data above, each of the highest average values per item and the lowest average value per item in the indicators contained from the variables of Leadership Style (X1), Work Culture (X2), Work satisfaction (X3), and Employee Engagement (Y) can be seen in table 1.

Table 1. Recapitulation Analysis of the average value of the highest indicator and the lowest indicator of each variable

\begin{tabular}{|c|c|c|c|c|c|}
\hline \multirow[b]{2}{*}{ No } & \multirow[b]{2}{*}{ Variable } & \multicolumn{2}{|c|}{ The Highest Indicator } & \multicolumn{2}{|c|}{ The Lowest Indicator } \\
\hline & & Indicator & $\begin{array}{c}\text { Average value } \\
\text { per item }\end{array}$ & Indicator & $\begin{array}{c}\text { Average value } \\
\text { per item }\end{array}$ \\
\hline 1 & Leadership Style (X1) & $\begin{array}{l}\text { Inspirational } \\
\text { Motivation }\end{array}$ & 4.489 & $\begin{array}{c}\text { Individual } \\
\text { consideration }\end{array}$ & 4.010 \\
\hline 2 & Work Culture (X2) & $\begin{array}{l}\text { Attitudes } \\
\text { Toward Work } \\
\text { Tools }\end{array}$ & 4.613 & $\begin{array}{l}\text { Leadership } \\
\text { Policy }\end{array}$ & 3.667 \\
\hline 3 & Work Satisfaction (X3) & $\begin{array}{l}\text { conditions } \quad \& \\
\text { Working } \\
\text { conditions }\end{array}$ & 4.351 & Work colleague & 4.156 \\
\hline 4 & Employee Engagement (Y) & Vigour & 4.516 & Absorption & 4.151 \\
\hline
\end{tabular}

Source: private document (2020)

\subsection{Employee Engagement}

The results of the calculation of the descriptive statistical analysis show that the minimum score of the data collected is 118 , while the maximum score is 148 . The calculation results also show that the mean shows the number 130.49 , the median shows the number 130.00 , and the mode is at number 129 . The standard deviation shown is 6,459 , and variance shows the value 41,713 . The total score of data obtained was 9,787 . From the data, it can be seen that the diversity of data, due to the small standard deviation value (6.459), it approaches the mean value, and the data tends to be homogeneous. Minimum data $=118$, and maximum data $=148$ so that the range (range $)=30$, with a total data score of 9,787 . The total score obtained by this study can be used to view the engaging picture of the Ministry of Defense State Civil Apparatur by comparing the total empirical score with a theoretical score multiplied by $100 \%$, namely 9,787: $11,250 \times 100 \%=87.00 \%$. As such, the highest level of State Civil Apparatur involvement in the Ministry of Defense is generally at $87 \%$.

\subsection{Leadership Style}

The results of the calculation of the descriptive statistical analysis show that the minimum score of the data collected is 112 , while the maximum score is 143 . The calculation results also show that the mean indicates 128.60 , the median shows 129 , and the mode is 125 . The standard deviation shown is 8,439 , and the variance shows the value of 71,216 . The total score of data obtained is 9,645 . From the data, it can be seen that the diversity of data, due to the small standard deviation $(8,439)$, is close to the mean, and the data tends to be homogeneous. Minimum data $=112$, and maximum data $=143$ so that the range $($ range $)=31$, with a total data score of 9,645 . The total score obtained by this study can be used to see a picture of leadership style in the Ministry of Defense according 
to State Civil Apparatur perception by comparing the total empirical score with a theoretical score multiplied by $100 \%$, namely $9,645: 11,250 \times 100 \%=85.73 \%$. Therefore, in general, the assessment of leadership style in the Ministry of Defense according to State Civil Apparatur perception is highest at $85.73 \%$.

\subsection{Work Culture}

The results of the calculation of the descriptive statistical analysis show that the minimum score of data collected is 102 , whereas the maximum score is 145 . The calculation results also show that the mean indicates 126.83 , the median shows 126.00 , and the mode is 120 . The standard deviation is shown 8,322 , and variance shows a value of 69,253 . The total score of the data obtained is 9512 . From the data, it can be seen that the diversity of Work Culture variable data, because the standard deviation value is small $(8,322)$, it approaches the mean value and the data tends to be homogeneous. Minimum data $=102$, and maximum data $=145$ so that the range (range) $=43$, with a total data score of 9,512 . The total score obtained by this study can be used to see the picture of work culture in the Ministry of Defense by comparing the total empirical score with a theoretical score multiplied by $100 \%$, namely 9,512: $11,250 \times 100 \%=84.55 \%$. Therefore, in general, the work culture in the Ministry of Defense is highest at $84.55 \%$.

\subsection{Work Satisfaction}

The results of the calculation of the descriptive statistical analysis show that the minimum score of data collected is 108 , while the maximum score is 145 . The calculation results also show that the mean indicates 126.32 , the median shows 125.00 , and the mode is 120 . The standard deviation is shown 7,632, and variance shows a value of 58,248 . The total score of data obtained is 9,474 . From the data, it can be seen that the variability of Work satisfaction variable data, because the value of the standard deviation is small $(7,632)$, it approaches the mean value and the data tends to be homogeneous. Minimum data $=108$, and maximum data $=145$ so that the range (range) $=37$, with a total data score of 9,474 . The total score obtained by this study can be used to see the description of work satisfaction in the Ministry of Defense by comparing the total empirical score with a theoretical score multiplied by $100 \%$, namely 9,474: $11,250 \times 100 \%=84.21 \%$. Therefore, in general, State Civil Apparatur work satisfaction at the Ministry of Defense was highest at $84.21 \%$. The results of the calculations show that all coefficients between variables are positive. This shows that there is a positive relationship between variables contained in the structural model.

\section{Discussion}

Leadership Style has a positive and significant direct effect on Employee Engagement because the indicators that contribute are quite large. Of the four Leadership Style indicators, all contributed above the average value of 4.0, namely inspirational motivation indicators with an average value of 4,489, idealized influence indicators with an average value of 4,383, intellectual simulation indicators with an average value of 4,324 , and indicators individual consideration with an average value of 4,010. Then the Employee Engagement variable has 3 (three) indicators, all of which also have an average value above 4.0, namely: vigor indicator with an average value of 4,516, dedication indicator with an average value of 4,412, and absorption indicator with an average value an average of 4,121. This is in line with the statement from McBain (2007) that one of the factors that influence employee engagement is leadership because leadership, according to Kreitner and Kinicki (2011), is the process by which individuals influence a group of individuals to achieve common goals. As stated by Robbins and Judge (2009), leadership includes influence and attention to shared goals. By applying the right leadership style, the organization will be able to direct and foster a sense of engagement for all its employees. Employees who are engaged will contribute optimally to the achievement of organizational goals, because by having highly engaged employees will become very involved and proud to work for their organizations (Recky \& Nazaruddin, 2015). The organization consistent with the opinion of Stoner, Freeman, and Gilbert (Simonet \& Tett, 2013), which explains that leadership is the process of directing and influencing the task-related activities of group members.

All indicators of the Work Culture variable, both included in the State Civil Apparatur Mental Attitude dimension, and Leadership Behaviour, can have a positive and significant direct effect on Employee Engagement because generally, this variable has a high average value. Indicators of attitude toward work tools have an average value of 4,613. On the other side, indicators of work ethic have an average value of 4,487. indicators of understanding of the meaning of work have an average value of 4,329, indicators of work behavior have an average value of 4,327 , indicators of attitude towards working time has an average value of 4,258 , an indicator of attitude to work has an average value of 4,193, an indicator of attitude to the work environment has an average value of 4,130, an indicator of leadership model has an average value of 4,070. A policy indicator of leadership has an average value of 3,667. The results of indicator consistent with Robbins's opinion in Khuzaeni et al. (2013), which states that work culture is: "... was practically contained some definitions of the pattern of values, attitudes, behaviour, intentions, and results of the work, including any instruments, work systems, technology, and the language it is used. According to Federman (2009), engaged employees will have the character: always focus when 
completing their work and in subsequent work assignments, be aware of the part of a larger team, be able to organize work, and have mature behaviour in working. Such work behavior clearly shows that the State Civil Apparatur concerned adheres to positive work culture values that can have an impact on State Civil Apparatur involvement. This is in line with the opinions of Ugargol and Patrick (2018), who state that engaged employees will always try to provide excellent work results, commit to their goals, use their intellectual abilities to make the best choices, and be able to ensure that what they are doing is right and in accordance with objectives to be achieved and will make decisions to correct if necessary. Meanwhile, Schaufeli and Bakker (2002) explained that one of the characteristics of engagement is the behaviour shown by the willingness to work hard and the desire to stay in the organization. The behaviour referred to in the study of Schaufeli and Bakker (2002) can be interpreted as employee behaviour at work commensurate with the work culture.

Work satisfaction has a positive and significant direct effect on Employee Engagement due to all indicators that contribute greatly. The six indicators of Work satisfaction, all contributed above the average value of 4.0, namely indicators of satisfaction with working conditions and atmosphere with an average value of 4,351. Work satisfaction refers to psychological conditions, perceptions, and individual evaluations of work and works environment, which is represented in the thoughts, feelings, and tendencies of one's actions, both positive and negative (Wollard, 2011). Because this condition is individual, then the level of satisfaction of a person can differ according to the prevailing value system in him. Penna in Ahlowalia et al. (2014), has developed a model from the results of his research entitled: "Meaning at Work Research," which he called "Hierarchy of Engagement" by adopting "Maslow Need Hierarchy Models." At the lower level, Penna stated that the basic need for employees to feel engaged is pay and benefits. Research from Schiemann (2011) concludes that employees who have a high attachment can influence the quality of employees in completing work, the quality of work tends to be satisfying, and the impact on low desire to leave work.

The results of this study are in line with Weinberger's leadership (2009), which is stated the interaction, relationships, and influence between leaders and those they lead. Leadership can also function based on the leader's power to invite, influence, and move people to do something, for the achievement of certain goals (Tuffour, Gali, \& Tuffour, 2019). According to Walter Nordi (Vermeeren, Kuipers, \& Steijn, 2014), leadership is an ability to influence the flow of energy and funds available to achieve a goal that is different from other goals. Therefore, the results of the research finding in line with Stoner, Freeman, and Gilbert (Onabajo, 2006) that leadership was influencing the task-related activities of group members. According to Zang and Li (2013), culture in organizations has many influences on organizational performance that have an impact on the psychological aspects of individual employees, groups, or even the organization as a whole. Psychological aspects of individual employees are what is meant by Zang and $\mathrm{Li}$ (2013) can be interpreted as work satisfaction. working environment and conditions, as well as the work factor itself. Thus, the results of this study confirm the theories of Zang and Li (2013), Bellou (2010), and Lim (2010), as described above. Also, this study confirmed the results of research from Pattipawae (2011) and Burt's research (Anoraga, 2006). Pattipawae (2011) concludes that the benefits of work culture can change employee attitudes and behaviour to increase work productivity.

\section{Conclusion}

Based on the results of the statistical hypothesis test and discussion, this study produces the following conclusions. Leadership Style has a direct positive effect on Employee Engagement. Then, data finding results show that if the leadership style is applied correctly, it will result in the State Civil Apparatur of Ministry of Defense being engaged. Work Culture has a positive direct effect on Employee Engagement. That shows that if a positive work culture is applied correctly, it will result in an engaged Ministry of Defense of State Civil Apparatur. Work satisfaction has a direct positive effect on Employee Engagement. And then, if State Civil Apparatur work satisfaction at the Ministry of Defense is fulfilled, it will result in the State Civil Apparatur Ministry of Defense being engaged. Leadership Style has a direct positive effect on Work satisfaction. If the leadership style is implemented well, it will result in an increase in the work satisfaction of the Ministry of Defense of State Civil Apparatur. Work Culture has a positive direct effect on Work satisfaction. That shows that if a positive work culture can be implemented well in the Ministry of Defense, it will result in an increase in the work of the Ministry of Defense of State Civil Apparatur. Leadership style has a direct positive effect on work culture.

Based on the conclusions of the research results, the theoretical implications can be explained. Testing and analysis of the discussion, this study implies that theories related to leadership style, work culture, work satisfaction, and employee engagement can be used as a basis for human resource management research. Besides, the Ministry of Defense needs to develop a leadership style that supports the realization of the State Civil Apparatur Employee Engagement. Referring to the results of this study, the appropriate leadership style used is the transformational leadership style. Therefore, according to empirical evidence, leaders in the Ministry of Defense can develop a transformational leadership style to realize State Civil Apparatur Employee Engagement in the Ministry of Defense. The need to foster and develop a positive work culture at the Ministry of Defense to support the realization of the State Civil Apparatur Employee Engagement in the Ministry of Defense. Based on the results of this study, a work 
culture that needs to be nurtured and continuously developed is State Civil Apparatur positive attitude and behaviour in work, related to the use of work tools, work ethic, understanding of the meaning of work, behaviour at work, attitude towards work time, attitude towards work, attitudes towards the work environment, as well as exemplary leadership and policies. The need to increase State Civil Apparatur work satisfaction in the Ministry of Defense to support the realization of the State Civil Apparatur Employee Engagement in the Ministry of Defense. The results of this study, it turns out that the most dominant State Civil Apparatur work satisfaction at the Ministry of Defense is not driven by satisfaction with rewards/salaries or rewards for work (promotion), but rather by conducive working conditions and atmosphere and satisfaction with the work itself. It can be used as a basis by the Head of the Ministry that to improve State Civil Apparatur work satisfaction at the Ministry of Defense is more directed at creating comfortable working conditions and conditions and how State Civil Apparatur has pride in its work.

\section{References}

Ahlowalia, S., Tiwary, D., \& Jha, A. (2014). Employee Engagement: A Structured Theoretical Review. The International Journal Of Business \& Management, 2(6), 224-229.

Anoraga, P. (2006). Psikologi Kerja. Jakarta: PT Rineka Cipta.

Bass, B. M., \& Avolio, B. J. (1993). Transformational leadership and organizational culture. Public Administration Quarterly, 17(1), 112-121. https://doi.org/10.1152/ajpregu.1984.247.3.r405

Bellou, V. (2010). Organizational culture as a predictor of work satisfaction: The role of gender and age. Career Development International, 15(1), 4-19. https://doi.org/10.1108/13620431011020862

Dajani, M. A. Z. (2015). The Impact of Employee Engagement on Job Performance and Organisational Commitment in the Egyptian Banking Sector. Journal of Business and Management Sciences, 3(5), $288-295$. https://doi.org/10.12691/jbms-3-5-1

Dodani, S., \& LaPorte, R. E. (2005). Sunita Dodani Ronald E LaPorte. Journal of the Royal Society of Medicine, 98, 487-491.

Federman, B. (2009). Employee Engagement: A Roadmap for Creating Profits, Optimizing Performance, and Increasing Loyality. San Fransisco: Jossey-Bass A Wiley Imprint.

Golovics, J. (2019). Addressing the EU's East-West Brain Drain: Why a Tax Solution would be in Vain. New Perspectives, 27(2), 63-85. https://doi.org/10.1177/2336825x1902700204

Heckman, J. J. (2005). Rejoinder: 'The Scientific Model of Causality' - Response to Sobel. Sociological Methodology, 35(1), 135-150. https://doi.org/10.1111/j.0081-1750.2006.00166.x

Joseph, W. (2011). The Effects of Brain Drain on Haiti. McNair Scholars Undergraduate Research Journal, 3, $145-156$.

Khuzaeni, Idrus, M. S., Djumahir, \& Solimun. (2013). The Influence of Work Culture, Work Stress to the Work satisfaction and Employees Performance in the State Treasury Service Office in Jakarta, Indonesia. IOSR Journal of Business and Management, 9(2), 49-54. https://doi.org/10.9790/487x-0924954

Koech, P. M., \& Namusonge, G. (2012). The Effect of Leadership Styles on Organizational Performance at State Corporations in Kenya. International Journal of Business and Commerce, 2(1), 1-12. Retrieved from www.ijbcnet.com

Kreitner, R., \& Kinichi, A. (2011). Perilaku Organisasi. (Kelima; E. Suandy, ed.). Jakarta: Penerbit Salemba Empat.

Lim, T. (2010). Relationships among organizational commitment, work satisfaction, and learning organization culture in one Korean private organization. Asia Pacific Education Review, 11(3), 311-320. https://doi.org/10.1007/s12564-010-9087-z

MacKinnon, D. P., Warsi, G., \& Dawyer, J. H. (1995). A simulation study of mediated effect measures. Multivariate Behavioral Research, 30(1), 1-21. https://doi.org/10.1207/s15327906mbr3001

McBain, R. (2007). The practice of engagement: Research into current employee engagement practice. Strategic HR Review, 6(6), 16-19.

Obeidat, B. Y. (2016). Exploring the Relationship between Corporate Social Responsibility, Employee Engagement, and Organizational Performance: The Case of Jordanian Mobile Telecommunication Companies. International Journal of Communications, Network and System Sciences, 09(09), 361-386. https://doi.org/10.4236/ijcns.2016.99032

Onabajo, O. (2006). Proactive Corporate Management and the Dynamics of Public Relations. Journal of Social Sciences, 12(2), 119-124. https://doi.org/10.1080/09718923.2006.11978378

Pattipawae, R. D. (2011). Penerapan Nilai-Nilai Dasar Budaya Kerja dan Prinsip-Prinsip Organisasi Budaya Kerja Pemerintah Dengan Baik dan Benar. Jurnal Manajemen Dan Organisasi, 17(3), 31-44.

Pella, D. A., \& Inayati, A. (2011). Talent Management: Building Human Capital for Growth and Excellence. Jakarta: PT. Gramedia Pustaka Utama.

Preacher, K. J., \& Hayes, A. F. (2008). Asymptotic and resampling strategies for assessing and comparing indirect 
effects in multiple mediator models. Behavior Research Methods, 40(3), 879-891. https://doi.org/10.3758/BRM.40.3.879

Rachmawati, M. (2013). Employee engagement sebagai kunci meningkatkan kinerja karyawan (International Journal Review). Among Makarti, 6(12), 56-65.

Recky, R., \& Nazaruddin, N. (2015). Pengaruh gaya kepemimpinan terhadap kinerja pegawai bp3akb kabupaten indragiri hilir. Jurnal Analisis Manajemen, 1(1), 37-44.

Robbins, S. P. (2006). Perilaku Organisasi. Jakarta: PT Indeks Kelompok.

Robbins, S. P., \& Judge, T. A. (2009). Organizational Behavior (13th ed.). New Jersey: Pearson Education Inc.

Sanneh, L., \& A.Taj, S. (2015). Employee Engagement in the Public Sector: A Case Study of Western Africa. International Journal of Human Resource Studies, 5(3), 70. https://doi.org/10.5296/ijhrs.v5i3.8088

Schaufeli, W. B., Salanova, M., González-Roma, V., \& Bakker, A. B. (2002). The measurement of engagement and burnout: A two sample confirmatory factor analytic approach. Journal of Happiness Studies, 3, 71-92.

Schein, E. H. (2010). Organizational Culture and Leadership. New Jersey: John Wiley \& Sons.

Schiemann, W. A. (2011). Alignment, Capability, Engagement: Pendekatan Baru Talent Management untuk Mendongkrak Kinerja Organisasi. Jakarta: PPM.

Shuck, B., Nimon, K., \& Zigarmi, D. (2017). Untangling the Predictive Nomological Validity of Employee Engagement: Partitioning Variance in Employee Engagement Using Job Attitude Measures. Group and Organization Management, 42(1), 79-112. https://doi.org/10.1177/1059601116642364

Sibanda, P., Muchena, T., \& Ncube, F. (2014). Employee engagement and organisational performance in a public sector organisation in Zimbabwe. International Journal of Asian Social Science International Journal of Asian Social Science, 4(1), 89-99. Retrieved from http://www.aessweb.com/journals/5007

Siddhanta, A., \& Roy, D. (2010). Employee engagement Engaging the 21st century workforce. Asian Journal of Management Research, 170-189.

Simonet, D. V., \& Tett, R. P. (2013). Five perspectives on the leadership-management relationship: A competencybased evaluation and integration. Journal of Leadership and Organizational Studies, 20(2), 199-213. https://doi.org/10.1177/1548051812467205

Singh, J., \& Krishna, V. V. (2015). Trends in Brain Drain, Gain and Circulation: Indian Experience of Knowledge Workers. Science, Technology and Society, 20(3), 300-321. https://doi.org/10.1177/0971721815597132

Tambunan, T. (2012). Usaha Mikro Kecil dan Menengah di Indonesia : isu-isu penting. Jakarta: LP3ES.

Titien, T. (2017). Penyusunan dan Pengembangan Alat Ukur Employee Engagement. Psikohumaniora: Jurnal Penelitian Psikologi, 1(1), 113. https://doi.org/10.21580/pjpp.v1i1.958

Trang, S. D. (2013). Gaya kepemimpinan dan budaya organisasi pengaruhnya terhadap kinerja karyawan (Studi pada Perwakilan BPKP Provinsi Sulawesi Utara). EMBA, 1(3). https://doi.org/10.32832/inovator.v7i1.1462

Tuffour, J. K., Gali, A. M., \& Tuffour, M. K. (2019). Managerial Leadership Style and Employee Commitment: Evidence from the Financial Sector. Global Business Review. https://doi.org/10.1177/0972150919874170

Turriago-Hoyos, A., Thoene, U., \& Arjoon, S. (2016). Knowledge Workers and Virtues in Peter Drucker's Management Theory. SAGE Open, 6(1). https://doi.org/10.1177/2158244016639631

Ugargol, J. D., \& Patrick, H. A. (2018). The relationship of workplace flexibility to employee engagement among information technology employees in India. South Asian Journal of Human Resources Management, 5(1), 40-55. https://doi.org/10.1177/2322093718767469

Vermeeren, B., Kuipers, B., \& Steijn, B. (2014). Does Leadership Style Make a Difference? Linking HRM, Work satisfaction, and Organizational Performance. Review of Public Personnel Administration, 34(2), 174-195. https://doi.org/10.1177/0734371X13510853

Wahyudi. (2014). Laporan Tahunan 2014. Retrieved from Transparency International Indonesia website: https://riset.ti.or.id/corruption-perceptions-index-2014/

Weinberger, L. A. (2009). Emotional intelligence, leadership style, and perceived leadership effectiveness. Advances in Developing Human Resources, 11(6), 747-772. https://doi.org/10.1177/1523422309360811

Wollard, K. K. (2011). Quiet desperation: Another perspective on employee engagement. Advances in Developing Human Resources, 13(4), 526-537. https://doi.org/10.1177/1523422311430942

$\mathrm{Xu}$, J., \& Thomas, H. C. (2011). How can leaders achieve high employee engagement. Leadership and Organization Development Journal, 32(4), 399-416. https://doi.org/10.1108/01437731111134661

Zhang, X., \& Li, B. (2013). Organizational Culture and Employee Satisfaction: An Exploratory Study. International Journal of Trade, Economics and Finance, 4(1), 48-54. https://doi.org/10.7763/ijtef.2013.v4.259 